\title{
Triglav National Park, Slovenia, and its contribution to regional development
}

\author{
Matej Gabrovec, Blaž Komac, Jani Kozina, Katarina Polajnar Horvat, Janez Nared, Aleš Smrekar, Maja \\ Topole \& Mimi Urbanc (corresponding author)
}

Keywords: Triglav National Park, Slovenia, regional development, protected areas, ownership conflict, participation

\section{Abstract}

Triglav National Park is the only national park (NP) in Slovenia. Its protection measures have always been publicly disputed and its impact questioned. This paper identifies and assesses the impact of the park on regional development. It compares two kinds of data: the municipal development coefficient based on statistical data and residents' attitudes toward the park, based on analysis of a survey, newspapers, and public debates. Triglav NP is located in two regions: Goriška and Gorenjska. Our results show that the municipalities in Gorenjska are better developed; however, the development trends in these municipalities are decreasing, whereas in the Goriška region they are increasing, overall reducing the regional differences between the two parts of the park. Text analyses reveal that lack of clarity in the management, boundaries and funding of the park, as well as inconsistency with existing legislation and international standards, have resulted in constant conflicts, which have impeded regional development. We argue that, once the conflicts are solved and local communities perceive positive changes as a result of implementing the law, progressive effects developing the protected area will follow. Triglav NP has the potential for long-term positive impacts on regional development if there is sound legislation, if this legislation is effectively implemented and if an active participatory process is put in place.
Profile

Protected area

Triglav NP

Mountain range

Alps

Country

Slovenia

\section{Introduction}

After the Second World War, due to the communist regime in place in Yugoslavia, the regional development of protected areas in Slovenia differed from that in other Alpine regions. However, unlike in other Eastern European communist countries, the land continued to be privately owned - except property owned by large estates and family farms if their holdings exceeded a certain threshold. Private landowners had no political power and, when protected areas were being established, they were excluded from the consultations, even though their economic activity was limited by the adopted protection arrangements. After Slovenia's independence in 1991, a denationalization process began; in the case of Triglav NP extensive stretches of land, including the one in the centre, were returned to their previous owners. All of this caused many conflict situations.

Triglav NP is the only NP in Slovenia. It is located in the Julian Alps, in the north-western part of the country (Figure 1). The Julian Alps are part of the Southern Limestone Alps, the highest point is $\mathrm{Mt}$ Triglav $(2864 \mathrm{~m})$. Efforts to protect this region go back a long way, with the first protection initiatives being presented in the early $20^{\text {th }}$ century (Skoberne 2015). Several centuries prior to that the park area had been used for ironworking, Alpine dairy farming, and forestry. Iron had been extracted in various places on karst plateaux from prehistoric times up to the $19^{\text {th }}$

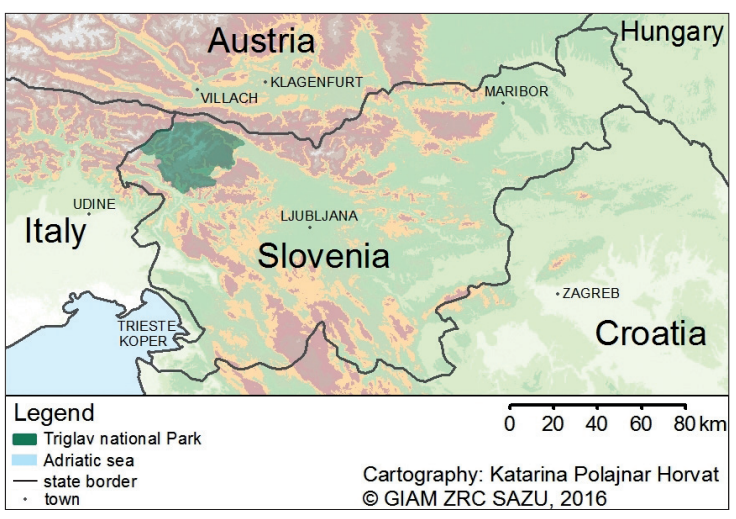

Figure 1 - Triglav NP lies in north-western Slovenia.

century. Only remains of some short shafts are visible today (Berginc et al. 1987). These activities were also connected with the human impact on the area, which in the second half of the $20^{\text {th }}$ century was joined by the impact of tourism and recreation: mountain lodges, holiday homes, ski resorts and a network of main roads (Rejec Brancelj \& Smrekar 2000).

Triglav NP is divided between two regions: the Goriška (Nova Gorica) and Gorenjska (Upper Carniola). The former includes the Upper Soča Valley and the municipalities of Tolmin, Kobarid and Bovec, and the latter includes the headwaters of the Sava River and the municipalities of Bohinj, Bled, Gorje, Jesenice and Kranjska Gora. The two parts of the NP differ in terms of their socio-economic characteristics and 
therefore the park has a different impact on their regional development.

In order to better understand the impact of Triglav NP on regional development, several milestones in the process of its protection are briefly presented below from the perspective of a significant paradigm shift regarding the concept of conservation (Mose \& Weixlbaumer 2007). In contrast to traditional concepts, which largely restricted human activity in protected areas, new approaches aim at consistent integration of conservation and development functions.

Over the past decade, there has been a very intense expert debate on the impact of protected areas on regional development (e. g. Hammer et al. 2012; Mayer \& Job 2014; Becken \& Job 2014), and this issue has increasingly been at the forefront in Slovenia as well (Lampič \& Mrak 2008; Hribar et al. 2011; Groznik Zeiler 2011). With regard to Triglav NP there is an increasing interest in visitors' relationship with the park and the role of its residents in maintaining the cultural landscape like Alpine meadows (Fikfak et al. 2014).

This paper explores whether the creation of Triglav NP has had a positive or negative impact on regional development. The answer to this question was sought in two ways. First, the park's impact on regional development was measured using selected quantitative indicators, whereby the local communities within Triglav NP were compared to municipalities outside Triglav NP. At the same time we analysed the perception of the local population. The support and participation of the local population is a precondition for a protected area's positive impact on regional development; this issue is presented through an analysis of selected local and national media and certain previous studies. Below both methods are described and their results presented.

The regional development is perceived as a comprehensive development of a territorially bounded area (Triglav NP), including social, economic and spatial aspects of development. In contrast to regional development we understand sustainable development as territorially unlimited, while its main focus is on longterm social, economic and environmental durability that will allow comparable development possibilities for future generations. Development as the most general term is perceived as spatial or temporal change of the area, society or institution.

\section{Milestones in the development of Triglav NP}

In 1924 a protected zone, referred to as the Alpine Protection Park, was established in the central part of today's Triglav NP (Figure 2). This was initiated by the Slovenian Museum Society, specifically, by its Nature Conservation Section, which concluded a 20 year lease agreement with the landowner. The landowner received compensation for lost pasture rental and all activities except for hunting and tourism visits were prohibited. The local residents, who had lost their traditional grazing rights, were not included in the negotiations on the protected status of this region (Skoberne 2015). The process thus started with a conflict between conservationists and locals, which has largely remained an issue until today. Even before the expiry of the lease agreement, the Natural History Society prepared a proposal in 1940 for expanding the protected area. A similar proposal was presented in 1959 by the Institute for Protection of Monuments of Slovenia. In 1961 a law designating Triglav NP was adopted, but the park covered only the territory of the pre-war Alpine Protection Park, with a few minor modifications of its boundaries. Soon after, various proposals were presented to expand the park, which was intended to include a major part of the Julian Alps (Peterlin 1975). A debate was organized on a bill prepared in the early 1970s. It included politicians, experts and government companies, but excluded the private landowners and residents. This bill was fairly modern in going beyond mere nature protection. One of its objectives was "to ensure to the resident population a modern living standard ..., opportunities for suitable employment and education, and improvement of the communal infrastructure and provision" (Jeršic 1975, 36). It was in line with the concept of polycentrism at that time (Drozg 2005).

Based on several years of expert and political discussions, the assembly of the Socialist Republic of Slovenia established Triglav NP in 1981 on approximately the same area as it has today. After the reestablishment of multi-party democracy in 1991, it became ever more evident that under the new circumstances the law was only conditionally applicable because it disagreed with the new spatial planning legislation. In order to avoid inevitable conflict as a result of the privatization of the state-owned property in the park, a legislation was adopted in 1994: the Act on Transforming the Ownership of Companies (with state capital) involved in tourism activities and whose real estate is located within Triglav NP. The relevant companies had to transfer their real estate within Triglav NP free of charge to the Triglav NP Development Promotion Fund (an incorporated company) through a contract. The revenue that the fund would obtain from managing its property would be earmarked for conservation, natural and cultural heritage protection, ecological rehabilitation of Triglav NP, promoting sustainable management of farmland and forests, facilitating development and promoting the park. The establishment of the fund was well conceived and could have generated income for the municipalities and their residents within the park, but unfortunately the fund was managed in a way that was neither in accordance nor in agreement with the act. It went bankrupt because of poor management (Družba za spodbujanje razvoja Triglavskega narodnega parka 2016).

After the year 2000, pressures to change the law on Triglav NP became stronger. The park's operation was the cause of dissatisfaction for both locals (Barbič 1994; del Negro 2009; Bajuk Senčar 2014) and 


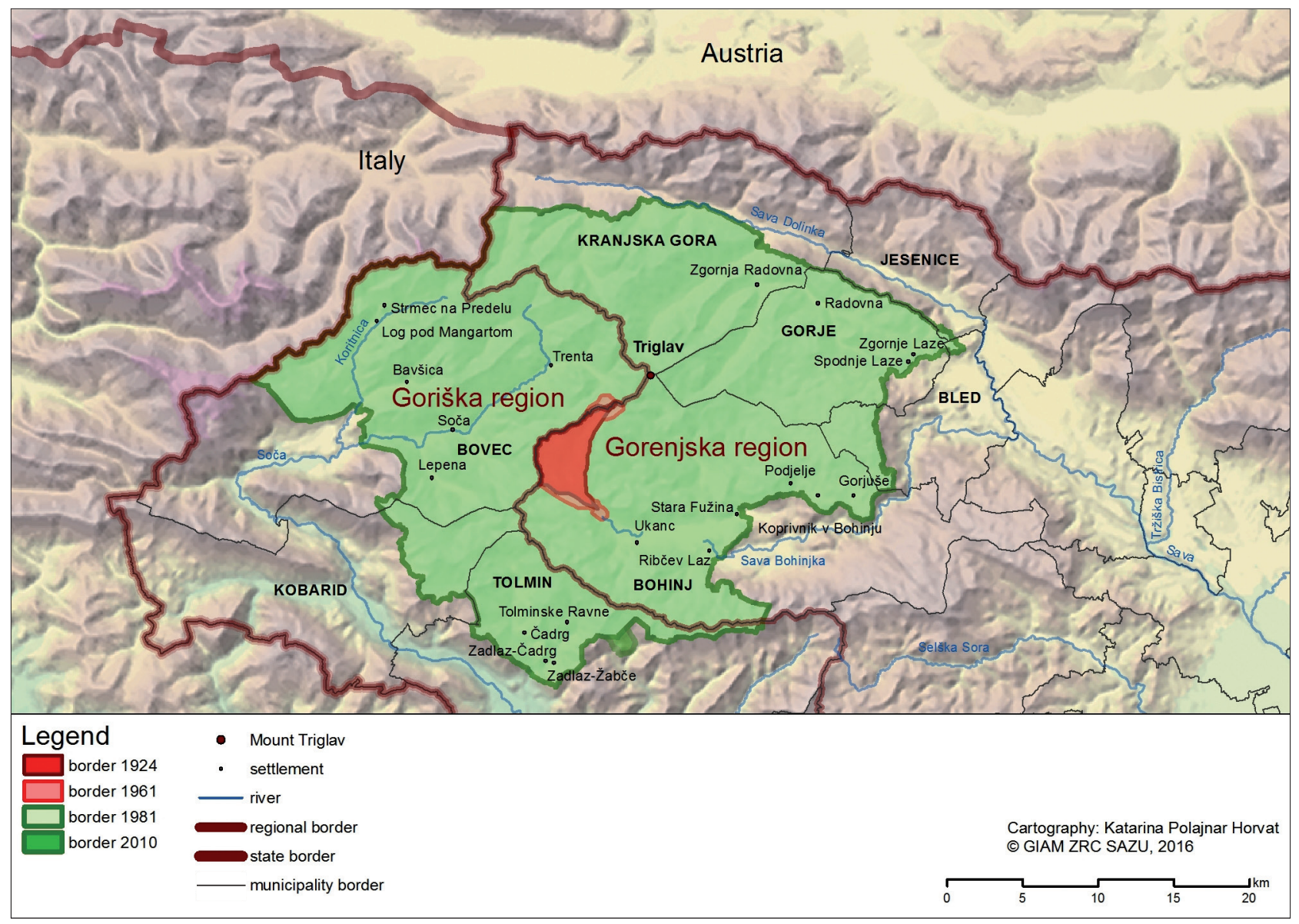

Figure 2 - Expansion of the protected area from 1924 to 2010.

conservationists. The latter established the Coalition of Non-Government Organizations for the Preservation of Triglav NP, which also held several meetings (Komac 2003). In 2010, after long discussions, a new Triglav NP Act was adopted specifying new protection arrangements and areas, and new development orientations regarding the manner of allocating incentives and funds to the park's local communities and residents. Now the park covers 83982 ha, $76.1 \%$ of which is core area. $54 \%$ of the land is privately owned, $24 \%$ is owned by local communities and only $22 \%$ is state-owned.

In addition to changes in the views on the protected area one can observe changes in the content of published research and discussions. The motive for the first protection in the 1920s was conservation, whereas Triglav NP guides (e.g., Berginc et al. 1987) published after 1981 treat natural and cultural heritage on an equal basis. Discussions on the threats posed to the protected area (e.g., Rejec Brancelj \& Smrekar 2000) are a constant, and over the past 20 years an increasing number of studies has focused on (sustainable) regional development within the park and on its residents as preservers of the cultural landscape (e.g., Bajuk Senčar 2014).

\section{Methods}

The municipal development coefficient was used to show the development of municipalities. The methodology for calculating this coefficient is determined in an ordinance issued by the Slovenian government and represents the ratio between the arithmetic mean of standardized indicator values in the municipality and the arithmetic mean of standardized indicator values in the country, in which the coefficient of the average development of municipalities in the country equals 1.00. The coefficient is calculated based on three groups of indicators: the municipality's development, its economic vulnerability and development potentials. The first group includes: corporate gross value added per employee, income tax base per resident and number of jobs per number of employed persons in the municipality. The second group consists of ageing index, registered unemployment rate and employment rate within the municipality. The third group includes supply of goods and public utility services, presence of cultural infrastructure, share of Natura 2000 sites and settlement. As a rule, the development coefficient is calculated every two years based on the data from previous years. The last five calculations from 2009 onwards are considered in this paper. In the case of Triglav NP, no municipality is located entirely within 
Table 1 - The respondent sample. *Source: http:/ / wnw.tnp.si/images/ uploads/5_socio-ekonomska_analiza.pdf ${ }^{* *}$ Source: own elaboration based on survey

\begin{tabular}{|l|r|r|r|r|r|r|}
\cline { 2 - 7 } \multicolumn{1}{c|}{} & \multicolumn{2}{c|}{ Sex [\%] } & \multicolumn{1}{c|}{ Age } & \multicolumn{3}{c|}{ Education [\%] } \\
\cline { 2 - 7 } \multicolumn{1}{c|}{} & Men & Women & Average & $\begin{array}{l}\text { Primary ed. } \\
\text { completed }\end{array}$ & $\begin{array}{l}\text { Secondary ed. } \\
\text { completed }\end{array}$ & $\begin{array}{l}\text { Tertiary ed. } \\
\text { degree }\end{array}$ \\
\hline Population* & 50 & 50 & 44.1 & 32.9 & 52.9 & 14.2 \\
\hline Sample* & 59 & 41 & 52.5 & 13.4 & 77.6 & 9.0 \\
\hline
\end{tabular}

the park, only a smaller share of settlements and population, and therefore the park's impact on development can be only conditionally inferred from these data. Hence the goal was to at least partly establish development at the level of settlements. Only some demographic data are available at this level; the ageing index is one. A demographic analysis was conducted based on the 1981 census (when the park was founded) and the 2011 census. It included 22 settlements from five municipalities in which the majority or all residents live within Triglav NP. Three of eight municipalities only include unpopulated areas within the park.

The residents' perception of their area's development often differs from the actual state of affairs, but it is key to understanding their relationship towards the protected area. The perception of the local residents of Triglav NP was assessed through an analysis of responses to a survey, which included 68 locals (Bajde et al. 2007). The survey focused on the relationship with the protection arrangements and the inclusion of locals in the protected area development. A third of the questionnaires were administered in the area along the Soča River and two-thirds were administered in the area along the Sava River, which roughly corresponds to the spatial distribution of the population. The respondent sample also roughly corresponds to the sex, age and education structure of the park's population (Table 1). The survey was carried out in April and May 2007.

The analysis of newspaper articles and public discussion minutes yielded a second source of data on the locals' changing relationship with Triglav NP. To this end, the documentation of the national newspaper publisher Delo was examined. It included articles published in Delo and other (daily, weekly, and monthly) newspapers since the early 1980s. Several hundred journalistic and other contributions on Triglav NP were found, mirroring the turbulent history of debates on Slovenia's only NP. In an effort to also include local discussions on the park, the local newspaper of the municipality of Bohinj (with the largest population within Triglav NP) was examined. The monthly Bobinjske novice has been published since 1996, at first as a supplement to the regional weekly Gorenjski glas, and from 1998 as an independent monthly. All of the households in the municipality of Bohinj have been receiving it for free for many years now and it is also freely available on the municipal website. At first it focused primarily on the news, but over the years it has increasingly discussed local issues. We analysed how

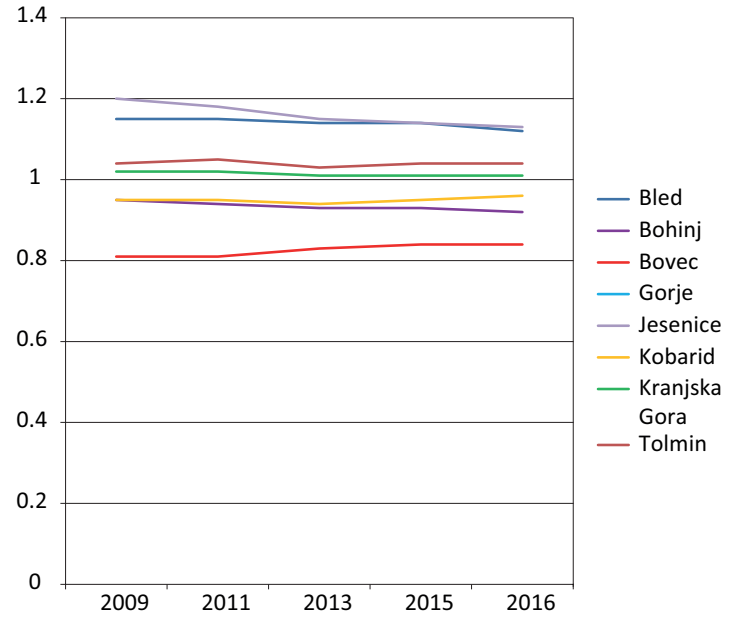

Figure 3 - Development coefficients of municipalities within Triglav NP.

the residents along the Soča River perceived the park by looking at comments on the supplemented draft Triglav NP Act presented during the draft act's public unveiling and public presentations in 2004. The frequency of words in the published text of this public discussion (approximately 25000 characters) was also analysed (Stališča do pripomb na dopolnjen predlog zakona o Triglavskem narodnem parku 2004). This is a document that reflects the opinion of residents at that time on the Act and indirectly speaks of their relationship with the park and life in it. Based on proposed amendments, we identified the topics that were significant for the park's residents. Special attention was paid to the part of the debate related to the part of the park along the Soča River.

\section{Results}

Development of the park's municipalities and their demographic conditions

A comparison of municipal development coefficients shows that the municipalities of Bovec, Gorje, Bohinj and Kobarid are poorly developed, whereas the municipalities of Kranjska Gora, Tolmin, Bled and Jesenice are above the Slovenian average. Hence, in terms of development, municipalities that only have an unpopulated portion of their territory in the park are in a better position. A comparison between the municipalities in the Soča Valley and Upper Carniola shows that the Upper Carniolan municipalities are better developed; however, the development trends in these municipalities are falling, whereas in the Soča Valley they are rising. It can be concluded that regional differences between the two parts of the park are diminishing (Figure 3).

Both within Triglav NP and in the park's municipalities in general, the demographic conditions are poorer than in the two regions as a whole in which the park is located (Goriška and Gorenjska). The area of the park along the Soča River is character- 
Table 2 - Ageing index and population changes. Source: Slovenian Statistical Office.

\begin{tabular}{|l|r|r|r|r|r|}
\cline { 2 - 6 } \multicolumn{1}{c|}{} & \multicolumn{1}{l|}{$\begin{array}{l}\text { Ageing } \\
\text { index }\end{array}$} & \multicolumn{2}{l|}{ Population } & \multicolumn{1}{l|}{$\begin{array}{l}\text { Population } \\
\text { index }\end{array}$} \\
\cline { 2 - 6 } & 1981 & 2011 & 1981 & 2011 & $2011 / 1981$ \\
\cline { 2 - 6 } \multicolumn{1}{l|}{$\begin{array}{l}\text { Goriška } \\
\text { Region }\end{array}$} & 61.1 & 129.1 & 118320 & 119163 & 100.7 \\
\hline $\begin{array}{l}\text { Municipalities } \\
\text { within the park }\end{array}$ & 88.7 & 156.9 & 16444 & 14839 & 90.2 \\
\hline $\begin{array}{l}\text { Settlements } \\
\text { within the park }\end{array}$ & 179.2 & 240.6 & 802 & 598 & 74.6 \\
\hline $\begin{array}{l}\text { Gorenjska } \\
\text { Region }\end{array}$ & 42.6 & 108.9 & 179250 & 203703 & 113.6 \\
\hline $\begin{array}{l}\text { Municipalities } \\
\text { within the park }\end{array}$ & 65.3 & 145.1 & 12898 & 13450 & 104.3 \\
\hline $\begin{array}{l}\text { Settlements } \\
\text { within the park }\end{array}$ & 98.2 & 138.4 & 1465 & 1572 & 107.3 \\
\hline
\end{tabular}

ized by poor age structure and a loss of population. In Gorenjska settlements within the park even present a slightly better demographic picture than the park's municipalities in general (Table 2). According to the Slovenian Statistical Office, 2185 people lived in the 22 analysed settlements in 2011, as opposed to 2340 in 1981 (Popis prebivalstva 1981 \& 2011). The total population thus decreased by 155 or $6.63 \%$. During the period from 1981 to 2011 the population declined in 13 settlements and grew in eight. In interpreting the population changes one must be careful because of the changed statistical definition and fictitious registrations of permanent residence in holiday homes for reasons of real estate tax evasion, especially in the Gorenjska part. A higher population growth index in settlements with a predominant holiday structure thus does not reflect the actual state of affairs (Marolt et al. 2012). The demographic trends between 1981 and 2011 were the same within the park and in both regions. Even in 1981, when Triglav NP was created, the settlements within the park had a less favourable age structure. Hence it can be concluded that the creation of the park itself did not have a significant impact on the demographic conditions.

\section{Residents' attitude towards the park and its development potentials}

The 2007 survey showed that the residents of Triglav NP mostly agreed with the area being protected $(85 \%)$, especially because this makes it possible to preserve the pristine natural environment and prevent any changes to it. Protection was better regarded in the Goriška region (92\%) than in Gorenjska (59\%). However, the attitude was different towards the protection arrangements. More than half of the respondents $(52 \%)$ thought they were too strict or unrealistic and only just over a third (35\%) thought they were suitable. People in the Soča Valley were more concerned with the overly strict rules of the protection arrangements $(71 \%)$ than in the area of the park along the Sava River (41\%). Complaints were primarily related to the numerous restrictive factors that prevented any modifications to the physical space, hindered business activity and required time-consuming bureaucratic procedures. The majority of respondents in both parts of the park believed it would make sense to use public funds, especially those secured from the government as the park's founder, for operating and maintaining the protected area. At the same time the majority $(62 \%)$ believed these funds were insufficient; this was expressed more strongly in the Soča Valley $(71 \%)$ than in the Sava Valley $(57 \%)$. Just under a third of respondents $(31 \%)$ were included in the development of Triglav NP in one way or another. This had mainly to do with their participation in associations, but partly also with their activities in tourism, agriculture and the park's management. At the beginning of 2015, Triglav NP employed a staff of 56, (Načrt upravljanja Triglavskega narodnega parka 2016-2025 2016). Jobs in the park service are relatively more important in the Soča Valley than in the Sava Valley. In the village of Trenta in the Upper Soča Valley, for instance, jobs in the Triglav NP information centre are the only ones apart from seasonal employment in tourism and agriculture.

The issues connected with Triglav NP were constantly discussed in Slovenian daily newspapers, which allows us to summarize debates on amending the legislation and the opinions on the suitability of the protection arrangements within the park, the quality of its management, violations of the law within the park, and so on. Here we briefly present just a few topics that the media covered more frequently. Violations and the failure to implement the Triglav NP Act were of course a constant, not only for residents and visitors, but also for the government and the local communities. After 1991 a legal vacuum was created because the Triglav NP Act did not conform to the new spatial and conservation legislation. The park management was unable to operate effectively due to a lack of funds and so it was forced to engage in activities of its own, especially commercial hunting, which was completely against the NP's fundamental objectives. The park residents expected greater benefits, a workable and sustainable funding system, agricultural tax exemptions and financial compensation for the restrictions within the park. The first decade of the $21^{\text {st }}$ century was characterized by fervent debates accompanying the adoption of a new act. The conservationists' views were often diametrically opposite to those presented by the local communities. Since the 2010 adoption of the Act, the main focus has been on adopting a management plan and the government's failure, because of the economic crisis, to fulfil its legal obligations to allocate incentives and to co-fund projects in the park.

Even towards the end of the $20^{\text {th }}$ century, at least part of the local population reflected on how the 1981 Triglav NP Act mainly imposed restrictions on the park residents while not providing them with any benefits. Nonetheless, hardly any articles on the 


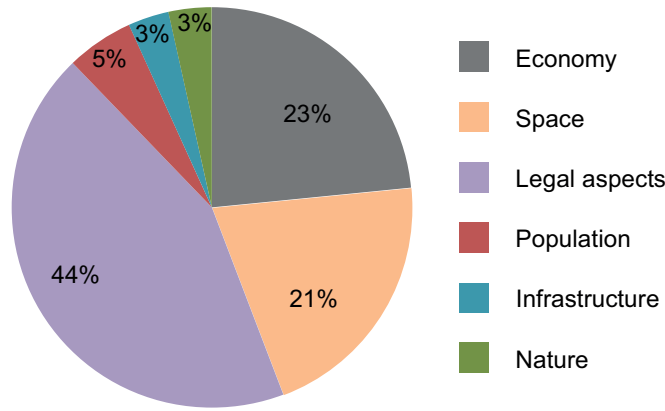

Figure 4 - Breakdown of statements by topic in the public debate on the draft Triglav NP Act.

preparation of a new bill on Triglav NP can be found in the newspaper Bohinjske novice before 2009; the bill was submitted for parliamentary reading in 2003 and adopted in 2010. Only a year before its adoption, a series of articles were published reflecting a hope for changes and positive effects for the local community, which was also confirmed by the mayor's statement that the upcoming Act offered "opportunities for the Bobinj Valley to develop normally and in harmony with the natural environment in tourism, agriculture, forestry, and fisheries" (Polajnar Peternelj 2010). Soon after the adoption of the new Act, the Bohinj Valley locals were disappointed to see that the government had not fulfilled its legal obligations. What bothered them most was the fact that it had not even begun arranging the envisaged $80 \%$ co-funding of infrastructure projects, preparing the National Location Plan for the Vogel Ski Resort as the central winter tourism site in the municipality, and relocating the park's headquarters to the Bohinj Valley, as specified by the new Act. As a result, at general meetings, which had a nearly $10 \%$ attendance, the locals called for exclusion of the populated areas, Lake Bohinj, and Mount Vogel from the park (with $90 \%$ of the votes in favour) (Lotric Ogrin 2012). In the municipality of Bohinj, tourism workers are dissatisfied with restrictions regarding the organization of various sports activities, such as mountain biking (Polajnar Horvat \& Drofenik 2015).

In the Soča Valley there have been various opinions on whether the park represented an opportunity or an obstacle ever since the park was created in 1981. Until the early 1990s, some locals even regarded the park and its management as "a tool of violence in the hands of the ruling class," whereas later on the relationship with the locals is said to have improved and become "more partner-like," considering that, according to the director at that time, the locals should "gain something from living in the park" (Smukavec 2011, 2). At the formal level, local participation is ensured in that the municipalities have their representatives in Triglav NP's council and the park representative is on the expert council of the Soča Valley Development Centre, which consists of seven members. This opens up possibilities for life in Triglav NP and also represents an opportunity (Simonič 2014).
The analysis of views on comments on the supplemented draft Triglav NP Act presented during its public unveiling and public presentations (Stališča do pripomb na dopolnjen predlog zakona o Triglavskem narodnem parku 2004) shows that, in addition to legal aspects (44\% of statements), the population in the Soča Valley was primarily concerned about economic aspects, whereas fewer statements were related to the population (5\%), nature, and infrastructure (3\% each). A relatively large number of statements were connected with space (Figure 4).

With regard to legal topics, the most frequent statements used were those referring to legislation (18.1\%), the measures that should be included in legislation or be implemented (11.5\%), and their evaluation (4.2\%). The most frequent statements used in relation to economic topics were those referring to development $(5.8 \%)$ and agriculture $(4.9 \%)$. Hunting was also an important topic $(4.5 \%$ of words used). Other topics mentioned included finance $(1.9 \%)$, forestry $(0.9 \%)$, trade and industry $(0.5 \%)$, exploiting natural resources $(0.4 \%)$ and the energy industry $(0.3 \%)$. It is interesting that tourism was not a particularly important topic $(1.8 \%)$ and it can be concluded that it was also not challenging. In terms of space, statements that were most frequently mentioned in the material were those related to limiting the park's size because during that time there were frequent discussions on the possible inclusion or exclusion of settlements into or from Triglav NP (13.9\%). Of the statements related to residents, locals $(3.7 \%)$ and the quality of life in the park $(0.6 \%)$ were mentioned most frequently. It is interesting that, despite the generally known park orientation towards conservation, expressions related to nature were not particularly frequent. Natural resources (without forests), primarily in terms of their exploitation, were only mentioned in $1.2 \%$ of the cases, nature protection and natural disasters were referred to in $0.9 \%$ of cases and plant species in $0.4 \%$.

\section{Discussion}

The development coefficients of the park's municipalities and the demographic analysis showed great differences between the areas of the park along the Soča and Sava Rivers in terms of regional development. The findings agree with those from other Alpine regions; namely, that parks have a "stimulating potential" primarily in their "peripheral rural areas" (Mose \& Weixlbaumer 2007). In terms of development challenges, Hammer et al. (2016) distinguish protected areas under the strong influence of nearby urban centres from rural peripheral parks. Characteristics of the former can be observed in the eastern, Sava Valley, part of Triglav NP, and of the latter in its western, Soča Valley, part. These data provide good insight into the differences within the park, but they make it difficult to determine the park's direct and indirect impact on development because this also depends on a number of other factors. 
Especially in the part of the park along the Sava River, a significant portion of land is privately owned; in addition, settlement and related activities, especially forestry and, in places, intensive tourism, extend to the vicinity of the most strictly protected zone. These two facts make comprehensive and long-term (i.e., sustainable) management of natural and social resources in the park practically impossible. Because settlement in Triglav NP is mainly concentrated in the Alpine valleys, whose surroundings lie within the protected area, another topic is relevant for Triglav NP: protection against dangerous natural processes, such as flash floods in streams; however, this is only possible through maintenance interventions in the protected area (Höchtl et al. 2005; Komac \& Zorn 2011). Therefore, at least in the medium term, one can expect that the long-standing problematic relations between the locals and the park managers and the failure to meet protection goals (Mose 2007) will continue. For example, this is evident from the analysis of articles in various newspapers that proved to be an excellent source for studying the relationship of various stakeholders with Triglav NP. The number of items on Triglav NP in the main Slovenian dailies exceeded initial expectations; the items were not limited to the periods of the public debate accompanying the adoption of new laws or management plans, but they appeared throughout, from the creation of the park until today - that is, throughout the period for which this documentation was examined. The documentation provides good insights into the relations between the protection initiators and the park's manager, on the one hand, and the local residents, on the other. This relationship was often characterized by conflict, which of course had a negative impact on the area's development; this is also confirmed by the highest frequency of legal expressions in the analysed texts. In professional circles there is consensus about the need to include the affected residents in the earliest possible stages of decision-making on protected areas (Hammer et al. 2012). The newspaper reports clearly show that the public was included too late and that the participatory process, which is vital for sustainable development (Nared et al. 2015a, b), was insufficient. The locals were not included more fully in the process until the stage of preparing the management plan, but their proposals were often rejected as not conforming to the Triglav NP Act (Bajuk Senčar 2014). The newspaper material collected makes it possible to conduct even more thorough analyses in the future.

A challenge for the future is a more detailed study of direct and indirect economic effects of the park. Such an analysis was carried out for German (Job et al. 2016) and wider European national parks (Mayer \& Job 2014). A comparative analysis of Alpine national parks (Job et al. 2003) included Triglav NP, also based on an interview with the then director of Triglav NP. Given the smaller population and poorer economic development, direct economic effects are relatively more relevant for the part of the park along the Soča River. For instance, the government funding of postearthquake recovery was 30\% higher there than outside the park (Šolar 2010), and the jobs in the public institute that manages the park are also relatively important. In addition, no estimates are as yet available on how much income the locals generate through higher agricultural subsidies and certain development incentives. The possibly increased tourism income resulting from the Triglav NP trademark also represents an interesting challenge for future research. On the other hand, an analysis of the losses in income due to restrictions on certain activities in the park still needs to be carried out. In the Bohinj Valley, complaints are primarily voiced against the prohibited expansion of the Vogel Ski Resort and artificial snow making there.

Nonetheless, Triglav NP has different developmental potentials that contribute to sustainable development. In terms of sustainable development, these potentials are not necessarily economic, but also include social, environmental or cultural aspects (Šmid Hribar et al. 2015) and international cooperation (Marzelli \& Lintzmeyer 2015).

\section{Conclusion}

A key factor for successful regional development of a protected area is trust between those promoting protection, or the managers, on the one hand, and the local population and landowners, on the other. In the municipality of Bohinj, which has the most residents living inside Triglav NP, the first protected area in the Triglav Lakes Valley was established against the will of the locals, who opposed it because of the loss of grazing rights. Under communist Yugoslavia, private landowners in the park were not included in decision-making about park management. After Slovenia attained independence, the government included various measures in the legislation for introducing development incentives within the park. Unfortunately, however, many of these were not carried out in practice due to poor management and / or the financial crisis. Thus, at least in the part of the park in Upper Carniola, the locals continue to lack trust in the park and their perception is that the park offers more limitations than advantages.

Thus Triglav NP does not have a uniform structure with regard to the economy, culture and the population. The western part of the park, which lies in the Soča Valley, is economically less developed. In this sparsely populated part of the park that is difficult to access, jobs in the public institute that manages the park are extremely important for the locals, who have also largely managed to exploit various development incentives. The calculated development indices also point to the positive impact of the park in the Soča Valley. 


\section{Acknowledgement}

This paper was written as part of the project J66854 cultural landscapes caught between public good, private interests and politics and the program P6-0101 Geography of Slovenia, financed by the Slovenian Research Agency.

\section{References}

Bajde, M., L. Černuta, N. Berki, G. Divjak Zalokar, P. Gostinčar, Š. Guštin, B. Jerebic, L. Kavalič, U. Košir, J. Kozina, H. Primožič, T. Lovšin, M. Novak, A. Paš, K. Peternelj, E. Pogačnik, M. Šteharnik, T. Štembergar, J. Tiran, S. Založnik \& E. Pirjevec 2007. Rąvojni potenciali iabranih zavarovanih obmořj v luci zaznavanja njibovih domačinov in obiskovalcev : strokovna ekspertiza : usmeritveni predmet II - Varstvo geografskega okolja. Ljubljana. IIn Slovene]

Bajuk Senčar, T. 2014. Načrt upravljanja Triglavskega narodnega parka in kultura dediščinskih praks. In: Fikfak J., T. Bajuk Senčar \& D. Podjed (eds.), Triglavski narodni park: akterji, dedišine: 9-25. Ljubljana. IIn Slovene]

Barbič, A. 1994. Sustainability and development. The case of Triglav National Park residents. Research reports: Agricultural issue 63: 223-240. Ljubljana.

Becken, S. \& H. Job 2014. Protected Areas in an era of global-local change. Journal of Sustainable Tourism 22(4): 507-527.

Berginc, M, J. Bizjak, I. Fabjan, S. Peterlin \& V. Strgar (eds.) 1987. The Triglav National Park. Bled.

del Negro, M. 2009. Schutrgebiete in Slowenien mit besonderer Berücksichtigung des Alpenraums. (IGF Forschungsberichte 3). [In German]

Drozg, V. 2005. koncepti policentrične ureditve Slovenije. Dela 24: 147-158. [In Slovene]

Družba za spodbujanje razvoja Triglavskega narodnega parka, d.d. Available at: http://www.druzba-tnp. si/node/20 (accessed: 19/03/16) [In Slovene]

Fikfak, J., T. Bajuk Senčar \& D. Podjed (eds.) 2014: Triglavski narodni park: akterji, dediščine. Ljubljana. IIn Slovene]

Groznik Zeiler, K. 2011. Razvojna vloga zavarovanih območij v Sloveniji. In: Nared. J., D. Perko \& N. Razpotnik Visković (eds.), Regionalni razvoj 3: 2332. Ljubljana. [In Slovene]

Hammer, T., I. Mose, T. Scheurer, D. Siegrist \& N. Weixlbaumer 2012. Societal research perspectives on protected areas in Europe. eco.mont 4(1): 5-12.

Hammer, T., I. Mose, D. Siegrist \& N. Weixlbaumer 2016. Parks of the future - Which future for parks in Europe? In: Hammer, T., I. Mose, D. Siegrist \& N. Weixlbaumer (eds.), Parks of the future!: 13-33. München.

Höchtl, F., S. Lehringer \& W. Konold 2005. "Wilderness": what it means when it becomes a reality - a case study from the southwestern Alps. Landscape and Urban Planning 70(1/2): 85-95.
Hribar, M., M. Šmid Hribar \& B. Erhartič 2011. Premislek o razvoju zavarovanih območij. In: Nared. J., D. Perko \& N. Razpotnik Visković (eds.), Regionalni razvoj 3: 11-21. Ljubljana. [In Slovene]

Jeršič, M. 1975. O osnutku predloga za slovenski narodni park v Julijskih Alpah. In: Peterlin, S. (ed.), 50 let Triglavskega narodnega parka: 31-42. Ljubljana. [In Slovene]

Job, H., D. Metzler \& L. Vogt 2003. Inwertsetzung alpiner Nationalparke. Eine regionalwirtschaftliche Analyse des Tourismus im Alpenpark Berchtesgaden. Münchener Studien zur Sozial- und Wirtschaftsgeographie 43. Kallmünz, Regensburg. [In German]

Job, H., C. Merlin, D. Metzler, J Schamel \& M. Woltering 2016. Regionalwirtschaftliche Effekte durch Naturtourismus in deutschen Nationalparken als Beitrag zum Integrativen Monitoring-Programm für Großschutzgebiete. BfN Skripten 431. Bonn-Bad Godesberg. [In German]

Komac, B. (ed.) 2003. Triglavski narodni park? Ljubljana. [In Slovene]

Komac, B. \& M. Zorn 2011. Vloga zavarovanih območij pri blažitvi naravnih nesreč. In: Nared. J., D. Perko \& N. Razpotnik Visković (eds.), Regionalni razvoj 3: 113-126. Ljubljana. [In Slovene]

Lampič, B. \& I. Mrak 2008. Vrednote, vrednosti in razvojni potenciali območij varovanja. Dela (29): 145159. [In Slovene]

Lotrič Ogrin, P. 2012. Z zbora občanov. In: Bohinjske novice 11(15): 2-3. [In Slovene]

Marolt, M., U. Smukavec, S. Zupan \& Ž. Mlekuž 2012. Socio-ekonomska analiza Triglavskega narodnega parka. In: Kus Veenvliet, J. (eds.), Izhodišca za Nă̌rt upravljanja Triglavskega narodnega parka 2012-2022: 8-58. Bled. [In Slovene]

Marzelli, S. \& S. Lintzmeyer 2015. Transnational needs of sustainable spatial development in the Alps: results from an analysis of policy documents. Acta geographica Slovenica 55(2): 351-361.

Mayer, M. \& H. Job 2014. The economics of protected areas - a European perspective. Zeitschrift für Wirtschaftsgeografie 58(2-3): 73-97.

Mose, I. 2007. Hohe Tauern National Park: A Model for Protected Areas in the Alps? In: Mose, I. (eds.), Protected Areas and Regional Development in Europe: 99-113. Farnham, Burlington.

Mose, I. \& N. Weixlbaumer 2007. A New Paradigm for Protected Areas in Europe. In: Mose, I. (eds.), Protected Areas and Regional Development in Europe: 3-19. Farnham, Burlington.

Načrt upravljanja Triglavskega narodnega parka 2016-2025. Available at: http://www.tnp.si/images/ uploads/13_NU-TNP_predlog-cistopis_september-2015.pdf (accessed: 19/08/16) [In Slovene]

Nared, J., N. Razpotnik Visković, D. CremerSchulte, R. Brozzi \& F. Cortines Garcia 2015a. Achieving sustainable spatial development in the Alps through participatory planning. Acta geographica Slovenica 55(2): 363-373. 
Nared, J., N. Razpotnik Visković \& B. Komac 2015b. Sustainable spatial development in the Alps. Acta geographica Slovenica 55(1): 161-163.

Peterlin, S. (eds.) 1975. 50 let Triglavskega narodnega parka (Fifty Years of the Triglav National Park). Ljubljana. [In Slovene]

Polajnar Horvat, K. \& U. Drofenik 2015. Opportunities for developing mountain biking in the $\mathrm{Mu}$ nicipality of Bohinj. Acta Geographica Slovenica 55(2): 317-335.

Polajnar Peternelj, M. 2010. „Če bo zakon o Triglav National Park v predlagani obliki sprejet, bomo Bohinjci veliko pridobili, intervju s Francem Kramarjem, županom občine Bohinj«. Bohinjske novice 1(13): 4-5. Bohinj. [In Slovene]

Rejec Brancelj, I. \& A. Smrekar 2000. Gorska ranljiva območja - primer Triglavskega narodnega parka. Geographica Slovenica 33(I): 47-69. [In Slovene]

Simonič, P. 2013. Naravne, gospodarske, politične in demografske danosti Trente v Triglavskem narodnem parku. Traditiones 42(2): 69-84. [In Slovene]

Skoberne, P. 2015. Od prispodobe konca sveta do narodnega parka. In: Zorn, M. \& D. Kladnik (eds.), Dolina Triglavskib jezer: 13-25. Ljubljana. [In Slovene]

Smukavec, J. 2011. Triglavski narodni park včeraj, danes in jutri. Okrogla miza Triglavski narodni park včeraj, danes, jutri. Okrogla miza, Bovec. Available at: http://www.tnp.si/images/uploads/TNP_ vc $\%$ CC $\% 8$ Ceraj,_danes,_jutri,_Joz $\%$ CC $\% 8 C$ e_Skumavec.pdf (accessed 13/1/16). [In Slovene]

Stališča do pripomb na dopolnjen predlog zakona o Triglavskem narodnem parku 2004. Državni zbor Republike Slovenije. Ljubljana. Available at: https:// www.dz-rs.si/wps/portal/Home/deloDZ/zakonodaja/izbranZakonAkt?uid=C12565D400354E68C1256 EB300334996\&db=kon_zak\&mandat $=I V \&$ tip $=$ doc (accessed 13/1/16). [In Slovene]

Šmid Hribar, M., D. Bole \& P. Pipan 2015. Sustainable heritage management: social, economic and other potentials of culture in local development. Procedia - Social and Behavioral Sciences 188: 103-110.

\section{Authors}

\section{Matej Gabrovec}

Senior research fellow at the Anton Melik Geographical Institute of the Research Centre of the Slovenian Academy of Sciences and Arts (Ljubljana). PhD in Geography (University of Ljubljana). Main research areas: land use and land cover changes, transport geography, geomorphology. E-mail: matej@zrc-sazu.si

\section{Blaž Komac}

Senior research fellow at the Anton Melik Geographical Institute of the Research Centre of the Slovenian Academy of Sciences and Arts (Ljubljana). $\mathrm{PhD}$ in Geography (University of Ljubljana). Main research areas: geomorphology, natural hazards, geographic information systems. E-mail: blaz@rc-sazu.si

\section{Jani Kozina}

Research fellow at the Anton Melik Geographical Institute of the Research Centre of the Slovenian Academy of Sciences and Arts (Ljubljana). PhD in Geography (University of Ljubljana). Main research areas: urban and regional development, spatial planning, creative economy, innovation. E-mail: jani. kozina@zrc-sazu.si

\section{Katarina Polajnar Horvat}

Research fellow at at the Anton Melik Geographical Institute of the Research Centre of the Slovenian Academy of Sciences and Arts (Ljubljana). PhD in Environmental protection (University of Ljubljana). Main research areas: environmental protection, sustainable development, environmental awareness, understanding and changing environmental behaviour through participation processes. E-mail: katarina. polajnar@zrc-sazu.si

\section{Janez Nared}

Senior research fellow at the Anton Melik Geographical Institute of the Research Centre of the Slovenian Academy of Sciences and Arts (Ljubljana). $\mathrm{PhD}$ in Geography (University of Ljubljana). Main research areas: regional development and planning, participatory planning, economic geography. E-mail: janez.nared@zrc-sazu.si

\section{Aleš Smrekar}

Senior research fellow at the Anton Melik Geographical Institute of the Scientific Research Centre of the Slovenian Academy of Sciences and Arts (Ljubljana). PhD in Geography (University of Primorska). Main research areas: protection and interpretation of natural and cultural heritage, integral environmental pollution and environmental public awareness. E-mail: ales.smrekar@zrc-sazu.si

\section{Maja Topole}

Research fellow at at the Anton Melik Geographical Institute of the Research Centre of the Slovenian Academy of Sciences and Arts (Ljubljana). PhD in Geography (University of Ljubljana). Main research areas: physical geography, regional geography, land use changes, natural and cultural heritage protection, geoecology. E-mail: maja.topole@zrc-sazu.si

\section{Mimi Urbanc}

Senior research fellow at the Anton Melik Geographical Institute and deputy director of the Scientific Research Centre of the Slovenian Academy of Sciences and Arts (Ljubljana). PhD in Geography (University of Primorska). Main research areas: cultural landscapes, perception of cultural landscapes, representations of landscapes. E-mail: mimi.urbanc@ zrc-sazu.si 